\title{
A better welfare for nursing sows without increased piglet loss applying peri-parturition short term crating
}

\begin{abstract}
Summary
A housing for nursing sows is presented that allows the animals to move within the pen for most of the time until weaning of the piglets and thus increases welfare. Ten days before farrowing was expected the sows $(n=80)$ were stalled to Scan farrowing pens without restriction. They were allowed to move around and to get into contact with their neighbour animals. Three to five days before parturition the sows were confined to farrowing crates until 4-6 days after parturition. At that time the piglets ( $n=4075$ from 361 litters) reliably visited the heated and protected hiding area. Compared to conventional housing systems for nursing sows we observed no increased piglet loss by crushing. Hence, temporal confinement of the sows around farrowing offers a suitable method to increase well-being without impairing the economic achievement.
\end{abstract}

Key Words: pig, sow, farrowing crate, piglet crushing

\section{Zusammenfassung}

Titel der Arbeit: Verbessertes Wohlbefinden für säugende Sauen ohne erhöhten Ferkelverlust durch Anwendung peripartaler Kurzzeitfixierung

Es wird ein Verfahren für intensive Ferkelaufzucht vorgestellt, das säugenden Sauen mehr Bewegungsfreiheit bietet und so eine tiergerechtere Haltung ermöglicht. Zehn Tage vor dem erwarteten Abferkeltermin wurden die Sauen $(n=80)$ ohne Bewegungseinschränkung in Scan-Abferkelbuchten aufgestallt. Sie erhielten die Möglichkeit, ihre Umgebung zu erkunden und Kontakt zu Nachbarsauen aufzunehmen. Anschließend wurden sie peripartal in Ferkelschutzkörben fixiert (3-5 Tage prä partum). Vier bis sechs Tage post partum wurde die Bewegungseinschränkung wieder aufgehoben. Zu diesem Zeitpunkt suchten die Ferkel ( $\mathrm{n}=4075$ aus 361 Würfen) zuverlässig den geschützten und erwärmten Ferkelbereich der Bucht auf. Im Vergleich zu herkömmlichen Haltungen von ferkelführenden Sauen wurden keine erhöhten Erdrückungsverluste festgestellt. Die nur zeitweise Fixierung von Sauen um den Geburtszeitraum herum bietet daher eine gute Möglichkeit, tiergerechte Haltung zu verbessern, ohne die Leistung einzuschränken.

Schlüsselwörter: Schwein, Sau, Abferkelbucht, Erdrückungsverluste

\section{Introduction}

Given the present demand for animal products in the world and the European Community in particular, we are not able to grow farm animals completely under freerange conditions. This is the case for reasons of sustainability and protection of nature since we would have to cut down enormous areas of woodland and alter our environment substantially in order to keep so many farm animals free-ranging (BROOM, 1992). Hence, keeping farm animals intensively will be inevitable and increasing their welfare under this condition will still be a main topic.

It is for that reason that any attempts to increase the well-being of farm animals that are grown in large numbers are urgently required, keeping in sight a sufficiently economic production, however. 
In pig husbandry, the technique dominating to date for keeping farrowing and nursing sows is using a crate in order to protect the piglets. However, the restriction of the sow's ability to move has often been criticised with respect to animal welfare. It is well established that self-narcotisation by endogeneous opiates may occur under sustained aversive stimuli which also may lead to stereotypies like chewing or gnawing. This has been taken as a measure for poor welfare (BROOM, 1992). In fact an increase of opiate receptors has been demonstrated in movement restricted sows (ZANELLA et al., 1996). In an experiment with rats electrical potentials were measured in a brain area thought to be involved in experiences of well-being. When the animals were confined for hours in a way similar to farrowing and nursing sows the nervous activity was as strongly attenuated as under the influence of morphine. This might indicate a narcotic condition as a result of a prolonged fixation (MANTEUFFEL, 2001).

The main reason for fixation of sows during nursing is to prevent crushing of the piglets. However, restraint which may also be advantageous with respect to handling, does not seem to result necessarily in significant reductions of piglet crushing (SAMBRAUS, 1997). From a standpoint of animal protection innate behavioral demands for movement and nest building are not satisfied in farrowing crates (CURTIS, 1995). However, if pigs are to be housed with an emphasis on well-being the biological needs have to be met (AREY et al., 1991; HUTSON, 1992; PHILLIPS et al., 1992; JENSEN, 1993; JENSEN et al., 1993; PETCHY et al., 1993; LAWRENCE et al., 1994; CRONIN et al., 1996). If this is neglected well-being and health of the sows may be impaired. Given the general demand for a reduction of the medication of farm animals, especially with antibiotics, the improvement of the natural resistance against diseases by a reduction of stress seems highly desirable.

Several investigations revealed an increased number of metritis-mastitis and leg diseases in sows confined to farrowing crates (BÄCKSTRÖM et al., 1984; FRAZER et al., 1995; BROOM, 1995; CRONIN et al., 1996), well in accordance with results indicating that stress may affect immune reactions resulting in an increased susceptibility for infections (TUCHSCHERER and MANTEUFFEL, 2000). Hence, various pens that allow the sows more movement activities have been developed and tested in recent times. Those newly developed systems, however, have to keep the existing high standards of hygiene, safety, and productivity in piglet breeding. Moreover, the demands of sows and piglets regarding optimum comfort are different. We found, that a commercially manufactured pen allowing to restrict only temporarily the sow's ability to move around may present a suitable compromise between necessities of intensive production, the protection of the newborn piglets, and an increased comfort for the sow.

\section{Material and Methods}

The present survey includes 361 DLxDL litters (DL: Deutsche Landrasse, German Landrace) from 80 sows. It was performed at the experimental pig plant (EPP) at the Research Institute for the Biology of Farm Animals in the years 1999 and 2000.

Ten days before the expected parturition the sows were stalled in Scan farrowing pens (Jyden-Dantec, Danmark) which measure $2 \times 3 \mathrm{~m}^{2}$. These pens include a movable fence that allows the separation of a piglet area $\left(0.75 \mathrm{~m}^{2}\right.$, with a $70 \%$ plastic ceiling) and restricts lateral movements of the trunk of the sow. With an additional posterior 
gate backward movements can be restricted in addition, so that a situation similar to a farrowing crate is obtained (Fig. 1). There is no special helping equipment for lying down.

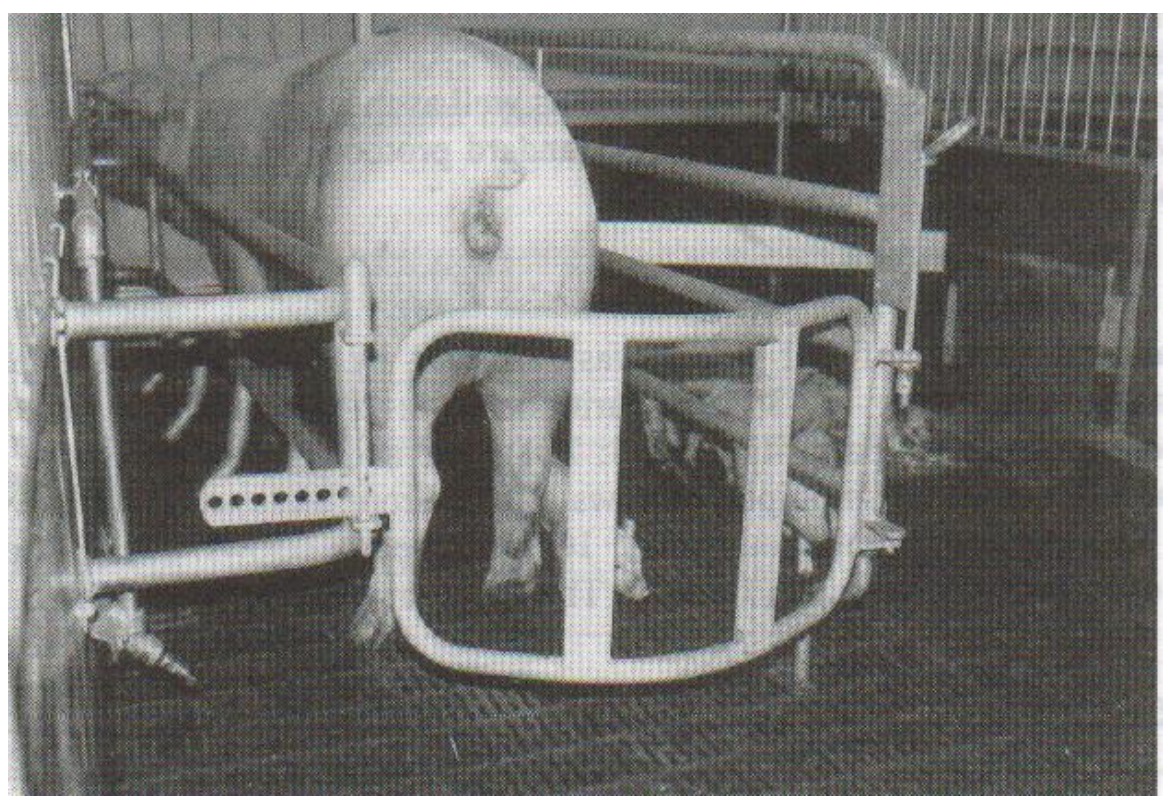

Fig. 1: A sow in the Scan farrowing pen with the crate closed (Sau in der Scan-Abferkelbucht mit geschlossenem Ferkelschutzkorb)

For the first 5 to 7 days after being stalled in the Scan pens the sows were allowed to move freely and they could get into contact with their neighbours. After this period of getting acquainted with the housing the sows were fixed for parturition. Four to six days after farrowing the restriction was terminated allowing the sow to move around in the pen except for the piglet hiding area (Fig. 2). The temperature in the sty was set to $19^{\circ} \mathrm{C}$, the piglet areas were equipped with an additional warm-water floor heating that guaranteed a suitable microclimate for the newborn.

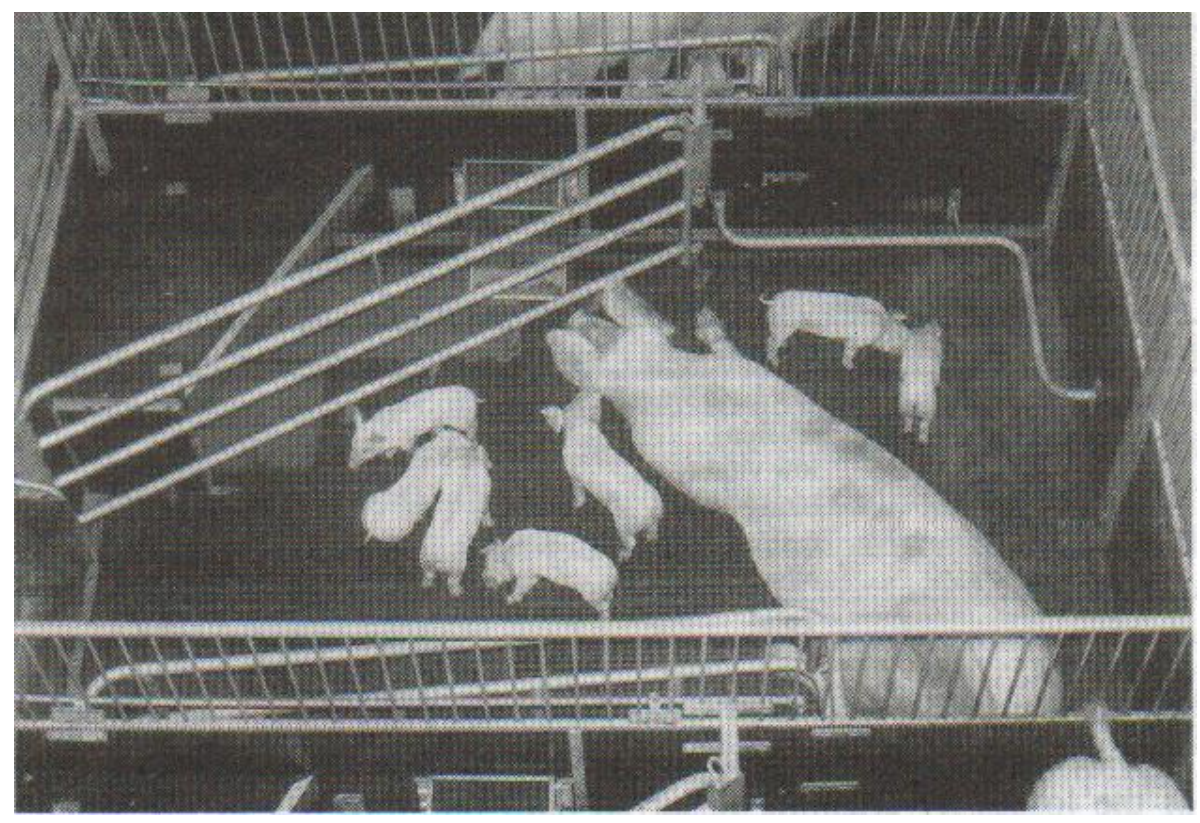

Fig. 2: Sow with piglets in the free-to-move condition of the farrowing pen. The piglet area is protected (Sau mit Ferkeln in der Bewegungsbucht mit abgegrenztem Ferkelschutzbereich) 
The sows were fed twice daily with commercial feed for nursing sows (TvP Denka $13,00 \mathrm{MJ})$, the piglets received supplement feed from the $7^{\text {th }}$ day of age. Both had ad libitum access to water.

The piglets were weaned at an age of 28 days.

The data of the sows' health, the litter sizes as well as the number and causes of piglets losses were registrated according to the standard protocol of the EPP and stored for later evaluation.

\section{Results}

The evaluated sample of 361 litters was farrowed by sows of various parturition numbers (parturition no. 1: $43 \%$; parturition no. 2: $24 \%$; parturition no. 3: $15 \%$; parturition no. 4: $11 \%$; parturition no. 5: $7 \%$ ). The average total litter size was 12.1 (primiparous sows: 11.2; multiparous sows: 12.7). From these were born alive on the average 11.3 piglets (primiparous sows: 10.3; multiparous sows: 12.1). The average number of litters / sow was 2.2 (Table 1). The average weight at birth was $1.3 \mathrm{~kg}$.

Table 1

Sow performances and piglet loss (Abferkelleistung und Ferkelverlust)

\begin{tabular}{llll}
\hline year & 1999 & 2000 & $1999 / 00$ \\
\hline Litter (n) & 170 & 191 & 361 \\
Primiparous sows (\%) & 55 & 29 & 43 \\
Average litter per sow (n) & 1.6 & 2.7 & 2.2 \\
Average of born piglets per sow (n) & 11.9 & 12.2 & 12.1 \\
Live born piglets per sow (n) & 11.1 & 12.2 & 12.1 \\
Weaned piglets per sow (n) & 9.5 & 9.6 & 9.5 \\
Average weight at birth (kg) & 1.3 & 1.3 & 1.3 \\
Average weight at weaning (kg) & 7.7 & 7.9 & 7.8 \\
\hline Total pre-weaning piglet loss (\%) & 16.3 & 17.4 & 16.9 \\
\hline
\end{tabular}

From these litters 9.5 piglets / litter were weaned on the average (primiparous sows: 8.8; multiparous sows: 10.1). The average weight at weaning was $7.8 \mathrm{~kg}$ (primiparous sows: 7.2; multiparous sows: 8.2). The average weight gain / day was $241 \mathrm{~g}$ (primiparous sows: 221 g; multiparous sows: 255 g).

On the whole, the data reveal the well known advantage of multiparous sows regarding litter sizes and breeding success.

Table 2

Causes for loss until weaning. (Verlustursachen bis zum Absetzen.)

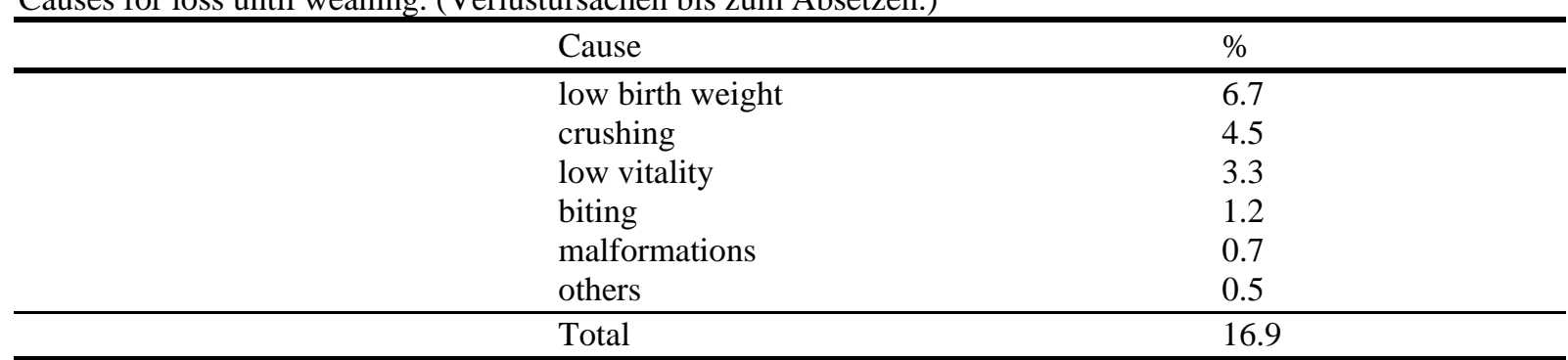

The total loss of piglets in relation to all live born piglets from all litters $(n=4075)$ was $16.9 \%$, the part that was crushed amounted to $4.5 \%$ (Table 2). Eighty-seven percent of the losses by crushing occurred until the third day of life when the sows were crated in the farrowing pens and basically the same situation existed as in 
standard farrowing crates. After that time only few losses by crushing occurred (Fig. 3).

As can be seen in Table 2 the main cause (6.7\%) for piglet losses was underweight at birth. The average birth weight was only $0.66 \mathrm{~kg}$ in these cases. These piglets were euthanasized. Rare reasons for piglet losses were maldevelopments, killing by the sow, non-vitalities, and lameness.

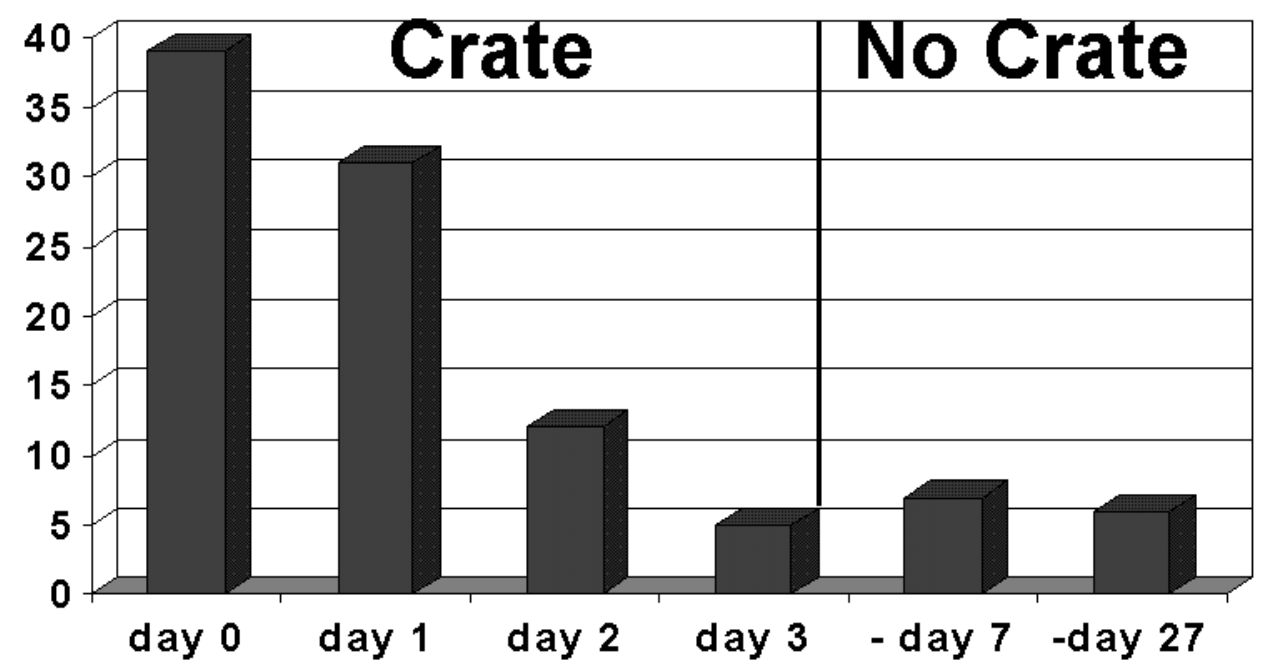

Fig. 3: Percentage of all crushed piglets (= $100 \%$ ) from day 0 (day of farrowing) until the $27^{\text {th }}$ day of age. The vertical line marks the time of removing the ferrowing crate (Prozentsatz aller erdrückten Ferkel $(=100 \%)$ von Tag 0 (Wurftag) bis zum Alter von 27 Tagen. Die vertikale Linie markiert den Zeitpunkt des Entfernens des Ferkelschutzkorbs.)

There were very few incidences of diseases in the sows which were allowed to move in the farrowing pens. In only two cases mastitis was diagnosed.

\section{Discussion}

In our sample of 361 litters yielded in two years the average number of piglets in a litter was well within the range of a good score. However, the average weight at birth amounted to $1.3 \mathrm{~kg}$ and thus was slightly below the optimum value claimed to be between 1.6 and $1.8 \mathrm{~kg}$ (RÖHE and KALM, 2000). This average slight underweight was due to the high number of primiparous sows (43\%) in the sample.

It is well-known that, in pigs, a relation exists between the weight at birth and the early postnatal vitality (ENGLISH et al., 1984; TUCHSCHERER et al., 2000). Big piglets with a well developed vitality tend to be behaviorally dominant, are earlier receiving colostral milk and stimulate the sow's teats more effectively. In an examination of TUCHSCHERER et al. (1994) piglets that reached weaning displayed higher blood levels of protein, glucose and gamma-globuline in comparison to lost or euthanasised piglets in the suckling period. Hence the conditions in our sample of litters was at best on average concerning the expectation on piglet losses.

WEBER (1991) recommended to fix sows only for a few days at farrowing. Accordingly, the sows in our sample were confined to the crates of the Scan farrowing pens only from 3 - 5 days before parturition until 4 - 6 days after. This yielded 9.5 weaned piglets / litter after 27 days with an average weight of $7.8 \mathrm{~kg}$. The total losses until weaning amounted to $16.9 \%$. Taking into consideration the high number of 
primiparous sows in our sample this was a reasonable result since the German average in the year 2000 was a loss of $16.4 \%$ until weaning in 20,000 breeding units with on the average 10.7 live-born piglets / litter (Anonymous, 2000).

Studies comparing free-to-move farrowing pens (Vario-Fit and Ulrich 2000) with conventional systems applying farrowing crates until weaning of the piglets were performed by the LVA HAUS DÜSSE (1997) and evaluated by HOY (2001). Using 857 litters they found slightly increased losses (about $17.5 \%$ total and $6.5-9.2 \%$ by crushing) in the free-to-move systems compared to $14.4 \%$ total losses and $4.8 \%$ by crushing in the conventional farrowing crates. From these results it was concluded that crateless pens cannot be recommended for piglet breeding. Similar results were published by EDWARDS and FRASER (1997) and MARCHANT et al. (2001).

When intensive production units with different housing systems are compared there is frequently only a shift between several causes of piglet losses (SAMBRAUS, 1997). In our survey the loss by crushing of piglets was $4.5 \%$ with a total loss of $16.9 \%$. HOY (2001), evaluating about 80,000 piglets in conventional systems reported losses by crushing of more than $5 \%$. Thus, in our sample the percentage was clearly not raised and, in addition, most of the crushing occurred in the first three days after farrowing when the sows were confined to the crates.

In conclusion, our results demonstrate that it is possible to improve the welfare of farrowing and nursing sows by restricting the time of crating to a minimum. The optimum duration for using a farrowing crate can still be a matter of discussion. It may well depend on peculiarities of an individual sow. So it may be necessary to restrain an aggressive or extraordinarily restless sow longer than usual in order to protect the stall personnel during the farrowing process or a medical treatment. With respect to animal welfare a well organised surveillance by professional staff will help the sow as well as the piglets. This will further reduce the time a sow has to be confined to the farrowing crate. Reducing this period may support the development and maintenance of maternal care and thus the piglet welfare, too.

For reasons which were described in the Introduction reduced stress in general (crating being part of this) will decrease the disease susceptibility of the sow. In fact, lameness, weakness of labor, prolonged birth, diseases of the urogenital system and metritismastitis-agalctia (MMA) are common problems in intensively housed sows. In plants keeping sows for breeding up to $80 \%$ of the animals develop MMA (STEIN, 1999) which, besides the clear impact on the sow's welfare, is highly undesirable as the disease has regularily to be treated with antibiotics. A further result of the sow's disease is deterioration of piglet development. Hence, a better welfare for the sow will also increase the economic output. In our sample only two cases of MMA occurred which might not be representative but may indicate a tendency, though.

We obtained good breeding results using farrowing crates in a comparatively short time around parturition. A next step could be the reduction of crating time or a use of the farrowing crate limited to special cases. It is reported that unrestricted birth may reduce the time for parturition for more than 70 minutes due to an undisturbed farrowing behavior (WEBER and TROXLER, 1988). Instead of forcing the sow to suppress most innate behavioral mechanisms that ease birth it may also be possible to make use of them. Swedish breeders who are not allowed to use farrowing crates since 1988 suffered from piglet losses of on the average only $15 \%$ from 1993 to 1996 
(SVC, 1997). This clearly demonstrates the suitability of crateless piglet birth and breeding.

However, since various restrictions of management regarding hygiene, the availability of staff, induction of birth etc. may exist our type of peri-parturition use of a farrowing crate may represent a good and practicable compromise between aspects of economic management and welfare of the sow. The application of sufficiently large pens which allow the sows to move around does not necessarily lead to increased piglet losses as a result of the housing technique if the sows can be crated in a critical peri-parturition period. This serves as well the protection of the piglets, if necessary, and guarantees hygiene and safety of work for the staff.

\section{References}

ANONYMOUS:

Aktuelle Zahlen aus den Erzeugerringen. Schweinezucht und Schweinemast, 48 (2000), 68-69

AREY, D.S.; PETCHEY, A.M.; FOWLER, V.R.:

The preparturient behaviour of sows in enriched pens and the effect of preformed nests. Applied Animal Behaviour Science 31 (1991), 61

BÄCKSTRÖM, L.; MORKOC, A.C.; CONNOR, J.; LARSON, R.; PRICE, W.:

Clinical study of mastitis-metritis-agalactia in sows in Illinois. Javma 185 (1984), 70-73

BROOM, D.M.:

Welfare and Conservation. In: R.D. RYDER (Editor): Animal Welfare and the Environment, Duckworth, London (1992), 90-101

BROOM, D.M.:

Measuring the effects of management methods, systems, high production efficiency and agricultural bioethics on farm animal welfare. In: Issues in Agricultural Biotechnics (Ed. T.B. MEPHAM), Nottingham Univ. Press, (1995), 319-334

CRONIN, G.M.; SIMPSON, G.J.; HEMSWORTH, P.H.:

The effects of the gestation and farrowing environments on sow and piglet behaviour and piglet survival and growth in early lactation. Applied Animal Behaviour Science 46 (1996), 175-192

CURTIS, S.E.:

The physical environment and mortality. In: The neonatal pig - development and survival. (Ed. M.A. VARLEY), CAB International, Wallingford (1995), 269-286

EDWARDS, S.A.; FRASER, D.:

Housing system for farrowing and lactation. The Pig Journal 39 (1997), 77-89

ENGLISH, P.R., SMITH, W.J., MACLEAN, A.:

The sow - Improving her efficiency. Farming Press, Ipswich, UK, (1984), 186-218

FRASER, D., PHILLIPS, P.A., THOMPSON, B.K., PAJOR, E.A., WEARY, D.M., BRAITHWAITE, L.A.:

Behavioural aspects of piglet survival and growth. In: The neonatal pig - development and survival. (Ed. M.A. VARLEY), CAB International, Wallingford (1995), 287-312.

HOY, S.:

EU-Richtlinie zur Haltung von Schweinen in der Diskussion. Bauernzeitung 42 (2001), 60-61

HUTSON, G.D.:

A comparison of operant responding by farrowing sows for food and nest-building material. Applied Animal Behaviour Science 34 (1992), 221-230

JENSEN, P.; VESTERGAARD, K.; ALGERS, B.:

Nestbuilding in free-ranging domestic sows. Applied Animal Behaviour Science 38 (1993), 245-255 JENSEN, P.:

Nest building in domestic sows: The role of external stimuli. Animal Behaviour 45 (1993), 351-358

LAWRENCE, A.B.; PETHERICK, J.C.; MCLEAN, K.A.; DEANS, L.A.; CHIRNSIDE, J.; VAUGHAN, E.; TERLOUW, E.M.C.:

The effect of environment on behaviour, plasma cortisol and prolactin in parturient sows. Applied Animal Behaviour Science 39 (1994), 313-330

LVA HAUS DÜSSE:

Abferkelbuchten im Test. Jahresbericht Haus Düsse (1997) 
MANTEUFFEL, G.:

Does nucleus accumbens activity reflect the hedonic value of an experienced situation? In: ELSNER, N.; KREUZBERG, G.W. (Editors): Göttingen Neurobiology Report 2001, Thieme, Stuttgart, New York (2001), 632

MARCHANT, J.N.; BROOM, D.M.; CORNING, S.:

The influence of sow behaviour on piglet mortality due to crushing in an open farrowing system. Animal Science, 72 (2001), 19-28

PETCHEY, A.M.; COLLINS, E.; BOON, C.:

The preferences of farrowing sows for different features of pen design. In: Proceeding of livestock environment IV, Coventry, UK (1993), 447-452

PHILLIPS, P.A., FRASER, D., THOMPSON, B.K.:

Sow preference for farrowing crate width. Canad. J. of Animal Science 72 (1992), 745-750

RÖHE, R.; KALM, E.:

Saugferkel: Ursachen für Verluste analysiert. SUS 48 (2000), 20-23

SAMBRAUS, H.H.:

STEIN, M.: Tierverhalten - Anzeiger für artgerechte Tierhaltung. Arch. Tierz., Dummerstorf 40 (1997), 26-34

MMA und Endotoxine: Antibiotische Behandlung oft unzureichend. Schweinezucht und Schweinemast 47 (1999), 12-13

SVC: Scientific Veterinary Committee: Report on the welfare of intensively kept pigs (BORELL, E., BROOM, D.M., CSERMELY, D., DIKJKHUIZEN, A.A., EDWARDS, S.A., JENSEN, P., MADEC, F., STAMATARIS, C.) Doc XXIV/B3/ScVC/0005/1997, Brussels, Internet Publication (1997), 1-191

TUCHSCHERER, M.; MANTEUFFEL, G. :

Die Wirkung von psychischem Stress auf das Immunsystem. Ein weiterer Grund für tiergerechte Haltung. Arch. Tierz., Dummerstorf, 43 (2000), 547-560

TUCHSCHERER, M.; PUPPE, B.; BUCHHOLZ, I.:

Soziale Organisationsstrukturen beim intensiv gehaltenen Schwein. 2.Mitt.: Physiologische Untersuchungen zur Saugordnung. Arch. Tierz., Dummerstorf 37 (1994), 65-75

TUCHSCHERER, M.; PUPPE, B.; TUCHSCHERER, A.; TIEMANN, U. :

Early identification of neonates at risk: Traits of newborn piglets with respect to survival. Theriogenology 54 (2000), 371-388

WEBER, R.; TROXLER, J.:

Die Bedeutung der Zeitdauer der Geburt in verschiedenen Abferkelbuchten zur Beurteilung auf Tiergerechtheit. KTBL-Schrift 323 (1988), 172-184

WEBER, R.:

Tiergerechte Aufstallungsformen in der Schweinehaltung. In: Tagungsbericht Tiergerechte Nutztierhaltung. Aufgabe und Ziel für Wissenschaft und Praxis. Institut für angewandte Tierhygiene, Eberswalde-Finow (1991), 146-177

ZANELLA, A.J.; BROOM, D.M.; HUNTER, J.C.; MENDL, M.T.:

Brain opioid receptors in relation to stereotypies, inactivity, and housing in sows. Physiol. \& Behav. 59 (1996), 769-775

Received: 2001-07-26

Accepted: 2001-12-05

Authors' address

Dr. BERND STABENOW, Prof. Dr. GERHARD MANTEUFFEL

Research Unit Behavioral Physiology

Research Institute for the Biology of Farm Animals

Wilhelm-Stahl-Allee 2

D-18196 Dummerstorf

Germany

E-Mail: stabenow@fbn-dummerstorf.de manteuff@fbn-dummerstorf.de 